\title{
Pedogenic Forms of Iron in Soils Developed from Four Parent Materials
}

\author{
Ayodele Owonubi \\ Forestry Research Institute of Nigeria; Federal College of Forestry, Jos; Department of Horticulture and \\ Landscape Technology, Jos, Palteau State, Nigeria.e-mail: ayowonubi@gmail.com
}

Received October 8, 2019; Revised November 20, 2019; Accepted December 13, 2019

\begin{abstract}
Information on the distribution of various forms of iron in soils are valuable in the study of soil genesis. The objective of this study was to to evaluate the pedogenic forms of iron in soils developed over basement complex and basaltic parent materials of the study area. Geologic units considered in the basement complex area were granite gneiss, biotite granite and migmatite. Stratified random sampling formed the basis for field work. Soil sampling was carried out by digging at least two soil profile pits in each geologic unit. Organically bound, amourphous and total iron oxides were estimated using $0.1 \mathrm{M}$ sodium pyrophosphate, acidified ( $\mathrm{pH} 3$ ) ammonium oxalate, and dithionite-citrate-bicarbonate method, respectively. The total Fe in the soil samples were determined after a mixed acid digestion. In general, total iron fractions were statistically similar among the soils of basement complex geologic units but significantly lower than those of soils derived from basaltic rocks. However, the distribution of iron oxide fractions was similar among the basement and basaltic geologic units. Furthermore, there were significant differences in the distribution of iron oxides in the B horizons of basement complex derived soils. Consequently, the quantity of iron oxides in the B horizon was in the order migmatite $>$ biotite granite $>$ granite gneiss. About $70 \%$ of total iron oxides in the soils over granite gneiss, biotite granite and basaltic rocks was amorphous in nature. Furthermore, total iron oxides constitute less than $20 \%$ of total clay both in the basement complex and basaltic soils.
\end{abstract}

Keywords: basalt, basement complex, iron, oxides, parent material

\begin{abstract}
ABSTRAK
Informasi tentang distribusi berbagai bentuk besi $(\mathrm{Fe})$ di dalam tanah sangat penting dalam mempelajari proses genesis tanah. Tujuan penelitian ini adalah untuk mempelajari bentuk-bentuk pedogenik dari besi (Fe) pada tanah yang terbentuk dari bahan induk basement complex dan batuan basalt. Unit geologi yang terdapat pada daerah penelitian dengan bahan induk basement complex meliputi granite gneiss, biotite granite dan migmatite. Pengambilan sampel secara acak dan berstrata dilakukan di lapangan. Pengambilan sampel tanah dilakukan dengan menggali paling sedikit dua profil tanah pada setiap unit geologi. Kompleks Fe-organik, amorfus Fe dan total Fe secara bertutur-turut diukur dengan menggunakan metode ekstraksi $0.1 \mathrm{M}$ sodium pyrofosfat, asam amonium oksalat $\mathrm{pH} 3$, dan dithionite-citrate-bicarbonate. Kandungan total Fe di dalam tanah ditentukan setelah proses destruksi dengan asam. Secara umum kandungan fraksi total Fe pada tanah yang terbentuk dari setiap unit geologi basement complex relatif sama, tetapi lebih rendah dibandingkan dengan kandungan total Fe pada tanah yang terbentuk dari batuan basalt. Namun, distribusi fraksi besi oksida relatif sama pada setiap unit geologi basement complex dan batuan basalt. Selanjutnya, terdapat perbedaan distribusi Fe oksida pada horizon B pada tanah yang terbentuk dari basement complex. Kandungan Fe oksida pada horizon B secara berurutan adalah migmatite $>$ biotite granite $>$ granite gneiss. Sekitar 70\% dari total Fe oksida pada tanah yang terbentuk dari granite gneiss, biotite granite dan batuan basalt berada dalam bentuk amorfus. Selanjutnya, total Fe oksida hanya berkisar $20 \%$ dari total kandungan liat pada tanah yang berasal dari basement complex dan batuan basalt.
\end{abstract}

Kata Kunci: Bahan induk, basement complex, batuan basalt, besi, oksida 


\section{INTRODUCTION}

Data analysis on the forms of $\mathrm{Fe}$ in soils are the major tools used to study soil genesis. Furthermore, information on distribution of iron oxide in soil profiles facilitates understanding of aggregate stability, organic matter dynamics and the stage and degree of soil development (Wagai and Mayer 2007). Porras et al. (2016) observed that Fe-(hydr)oxide minerals and Fe-organo-mineral complexes, despite being present in low concentrations, influenced the amount and stability of dense soil organic carbon fractions in some forest soils. In a study of rain forest, valley bottom soils, Fagbami and Ajayi (1990) observed that high values of Fe active ratios (0.5 3.11) indicate considerable hydration of crystalline oxides to amorphous forms in the soils, while decreasing values with depth indicate crystallinity of the oxides with depth. Bera et al. (2005) also reported that the crystalline iron oxides increase at the expense of the poorly crystalline forms with increasing soil age. Lateritic soils have been observed to contain significant higher amount of crystalline iron oxides compared to the poorly crystalline forms (Ko 2014). Similarly, Olatunji et al. (2015) also observed higher proportions of crystalline iron oxides in soil of a toposequence under semi humid tropical conditions.

The study area is located on the Jos Plateau. The Jos Plateau is a highland region in central Nigeria and is located between latitudes of $8^{\circ} 30^{\prime}$ and $10^{\circ}$ $10^{\prime} \mathrm{N}$ and longitudes of $8^{\circ} 20^{\prime}$ and $9^{\circ} 30^{\prime} \mathrm{E}$ (Olowolafe 2002). The climate is tropical continental with vegetation largely influenced by anthropogenic factors. Geology of the Jos Plateau comprises of Precambrian basement complex rocks (migmatites, gneisses and older granites), the Jurassic younger granites and the Tertiary as well as Quaternary volcanic rocks (mainly basalt, pumice, lava flows and ash deposits) (Macleod et al. 1971). A great extent of the Jos Plateau consists of post older basalt unconsolidated deposits which are underlain by granite; and forms the parent materials for many of the arable soils of the Jos Plateau. The objective of this study is to evaluate the pedogenic forms of iron in soils developed over basement complex and basaltic parent materials of the study area.

\section{MATERIALS AND METHODS}

\section{Field Work}

Stratified random sampling approach was used as the basis of the field work. Geologic units formed the basis of stratification. The geologic units considered for this study was basement complex (granite gneiss, biotite granite and migmatite) and basalt. Sampling points were located randomly in each geologic unit over the landscape of the Jos Plateau. Surface soil samples were obtained with the aid of an auger at a depth of $15 \mathrm{~cm}$. Profile pits representing average conditions for each geologic unit were dug and soil samples were obtained from the horizons.

\section{Analysis of Soil Samples}

Soil samples were air-dried, crushed with porcelain pestle and mortar and sieved to remove the materials greater than $2 \mathrm{~mm}$ (gravels and other coarse fragments). Organically bound iron oxides were extracted with $0.1 \mathrm{M}$ sodium pyrophosphate solution as described by Mckeague (1967). Total amorphous iron oxides were extracted with acidified (pH 3) ammonium oxalate solution, while the total iron oxides were determined by the dithionite-citratebicarbonate method of Mehra and Jackson (1960). The total Fe in the soil samples was extracted after a mixed acid digestion and determined with an atomic absorption spectrophotometer.

\section{Data Analysis}

One-way analysis of variance was used to analyse data of soils developed over basement complex rocks, whereas independent $t$ test was used to compare the data between soils developed over basement complex and basaltic rocks.

\section{RESULTS AND DISCUSSION}

\section{Iron Fractions in Soils Derived from Basement Complex Soils}

Data on the various forms of iron in the soils of study area is presented in Table 1 and 2. The distribution of total iron was statistically similar among the geologic units $(p>0.05)$. The total iron contents in the soils of the study area are low compared to the typical range of total iron in global soils (i.e. 5000 - 50, $000 \mathrm{mg} \mathrm{kg}^{-1}$ ) (Vance 1994). Similarly, the mean contents of total iron oxides $\left(\mathrm{Fe}_{\mathrm{d}}\right)$ estimated using a dithionite-citrate-bicarbonate extracation in the A horizon were statistically similar $(p>0.05)$ among the geologic units. In contrast, there were significant differences in the distribution of total iron oxides in the B horizons $(p<0.05)$ among the geologic units with the migmatite having the highest contents and granite gneiss having the lowest contents. The contents of total iron oxides in these soils are much lower than those reported by Ko (2014) for lateritic soils in Taiwan; and that reported 
by Yaro (2005) for plinthic soils formed over basement complex rocks (range: 3,800 to $47,900 \mathrm{mg}$ $\mathrm{kg}^{-1}$; mean: $\left.13,450 \mathrm{mg} \mathrm{kg}^{-1}\right)$. The results indicate as expected that these soils are to a great extent less weathered compared to those of the plinthic soils.
The distribution of armorphous iron oxides estimated using ammonium oxalate $\left(\mathrm{Fe}_{\mathrm{ox}}\right)$ was statistically similar among the geologic units $(p>0.05)$. The contents of total armorphous iron oxides were in general quite higher than that (range:

Table 1. Iron $(\mathrm{Fe})$ fractions $\left(\mathrm{mg} \mathrm{kg}^{-1}\right)$ in soils.

\begin{tabular}{|c|c|c|c|c|c|c|c|c|c|}
\hline Landform & Profile & Horizon & $\begin{array}{l}\text { Depth } \\
(\mathrm{cm})\end{array}$ & $\mathrm{Fe}_{\mathrm{T}}$ & $\mathrm{Fe}_{\mathrm{d}}$ & $\mathrm{Fe}_{\mathrm{ox}}$ & $\mathrm{Fe}_{\mathrm{p}}$ & $\begin{array}{l}\text { Ratio } \\
\mathrm{Fe}_{\mathrm{ox}} \text { : } \\
\mathrm{Fe}_{\mathrm{d}}\end{array}$ & $\begin{array}{l}\text { Ratio } \\
\mathrm{Fe}_{\mathrm{d}}: \\
\text { clay }\end{array}$ \\
\hline \multicolumn{10}{|c|}{ Granite gneiss } \\
\hline Crest & 1 & A & $0-10$ & 9985.72 & 1738.70 & 1180.99 & 422.02 & 0.68 & 0.12 \\
\hline \multirow{3}{*}{$\begin{array}{l}\text { Upper } \\
\text { foot slope }\end{array}$} & 2 & A & $0-12$ & 11547.62 & 1827.30 & 999.00 & 458.72 & 0.55 & 0.13 \\
\hline & & B & $12-30$ & 12523.80 & 1632.80 & 1059.20 & 788.99 & 0.65 & 0.07 \\
\hline & & $\mathrm{BC}$ & $>30$ & 14000.00 & 1543.30 & 886.94 & 541.28 & 0.57 & 0.06 \\
\hline \multirow{8}{*}{$\begin{array}{l}\text { Middle } \\
\text { foot slope }\end{array}$} & 3 & $\mathrm{~A} 1$ & $0-7$ & 16880.95 & 1858.00 & 1085.95 & 449.54 & 0.58 & 0.15 \\
\hline & & $\mathrm{A} 2$ & $7-20$ & 16761.91 & 2416.86 & 2379.34 & 559.63 & 0.98 & 0.20 \\
\hline & & BW1 & $20-40$ & 17071.43 & 1605.50 & 1204.70 & 495.41 & 0.75 & 0.09 \\
\hline & & BW2 & $40-57$ & 16928.60 & 1922.90 & 1333.45 & 348.63 & 0.69 & 0.11 \\
\hline & & BW3 & $57-72$ & 17928.60 & 1728.30 & 1224.75 & 293.58 & 0.71 & 0.07 \\
\hline & & BW4 & $72-107$ & 17928.57 & 2015.00 & 1156.20 & 1000.18 & 0.57 & 0.08 \\
\hline & & $\mathrm{BC}$ & $>107$ & 16547.62 & 1627.59 & 1577.69 & 1178.31 & 0.97 & 0.08 \\
\hline & \multicolumn{9}{|c|}{ Biotite granite } \\
\hline \multirow{5}{*}{$\begin{array}{l}\text { Upper } \\
\text { foot slope }\end{array}$} & 4 & Ap & $0-10$ & 14738.10 & 4060.54 & 2346.28 & 1119.27 & 0.58 & 0.29 \\
\hline & & $\mathrm{A} 2$ & $10-30$ & 14857.14 & 3179.31 & 2495.04 & 743.12 & 0.78 & 0.16 \\
\hline & & Bw1 & $30-70$ & 15857.14 & 3845.51 & 2354.60 & 697.25 & 0.61 & 0.16 \\
\hline & & Bw2 & $70-89$ & 15023.80 & 3547.71 & 2404.13 & 541.28 & 0.68 & 0.15 \\
\hline & & $\mathrm{BC}$ & $89-125$ & 15928.60 & 3436.02 & 3098.35 & 825.69 & 0.90 & 0.10 \\
\hline \multirow{5}{*}{$\begin{array}{l}\text { Middle } \\
\text { foot slope }\end{array}$} & 5 & Ap & $0-15$ & 6357.14 & 1351.72 & 1247.11 & 366.97 & 0.92 & 0.14 \\
\hline & & A2 & $15-27$ & 8595.24 & 1554.79 & 1408.26 & 697.25 & 0.91 & 0.11 \\
\hline & & Bw1 & $27-61$ & 9642.86 & 1708.05 & 995.04 & 183.49 & 0.58 & 0.09 \\
\hline & & Bw2 & $61-90$ & 11619.10 & 1861.30 & 1023.97 & 144.95 & 0.55 & 0.08 \\
\hline & & Bw3 & $>90$ & 13928.60 & 1447.51 & 1292.56 & 853.21 & 0.89 & 0.09 \\
\hline \multicolumn{10}{|c|}{ Migmatite } \\
\hline \multirow{4}{*}{$\begin{array}{l}\text { Upper } \\
\text { foot slope }\end{array}$} & 6 & Ap & $0-7$ & 15333.33 & 3665.90 & 1304.96 & 201.84 & 0.36 & 0.17 \\
\hline & & $\mathrm{Aw}$ & $7-38$ & 15357.14 & 3708.05 & 1218.18 & 209.74 & 0.33 & 0.15 \\
\hline & & B1 & $38-65$ & 14761.91 & 3378.54 & 1189.26 & 236.69 & 0.35 & 0.17 \\
\hline & & Bt2 & $65-81$ & 16214.29 & 3183.14 & 1032.23 & 871.56 & 0.32 & 0.13 \\
\hline \multirow{3}{*}{$\begin{array}{l}\text { Lower } \\
\text { foot slope }\end{array}$} & 7 & Aw1 & $0-21$ & 12452.40 & 4087.36 & 978.51 & 122.19 & 0.24 & 0.19 \\
\hline & & Bt1 & $21-57$ & 12619.05 & 4543.30 & 1114.88 & 188.73 & 0.25 & 0.21 \\
\hline & & $\mathrm{Bt} 2$ & $57-73$ & 12261.91 & 3945.60 & 329.75 & 119.40 & 0.08 & 0.14 \\
\hline \multicolumn{10}{|c|}{ Basalt } \\
\hline \multirow{9}{*}{$\begin{array}{l}\text { Upper } \\
\text { part of } \\
\text { mid foot } \\
\text { slope } \\
\text { Mid } \\
\text { upper } \\
\text { foot slope }\end{array}$} & 8 & Ap1 & $0-17$ & 20119.10 & 2202.70 & 1667.90 & 917.43 & 0.76 & 0.01 \\
\hline & & Bt1 & $17-45$ & 20404.70 & 2144.70 & 1669.55 & 605.51 & 0.78 & 0.01 \\
\hline & & $\mathrm{BCt} 2$ & $45-67$ & 20595.20 & 2175.00 & 1634.45 & 568.81 & 0.75 & 0.01 \\
\hline & & $\mathrm{BCt} 3$ & $>67$ & 19690.48 & 1970.60 & 1637.80 & 550.46 & 0.83 & 0.01 \\
\hline & 9 & Ap & $0-20$ & 20285.72 & 2240.30 & 1674.60 & 871.56 & 0.75 & 0.01 \\
\hline & & $\mathrm{AB}$ & $20-40$ & 20161.90 & 2056.00 & 1676.25 & 770.64 & 0.82 & 0.00 \\
\hline & & $\mathrm{Bt} 1$ & $40-72$ & 20500.00 & 2308.50 & 1646.20 & 550.46 & 0.71 & 0.01 \\
\hline & & BCt1 & 72-95 & 20761.90 & 2339.20 & 1656.20 & 513.76 & 0.71 & 0.01 \\
\hline & & $\mathrm{BC} 2$ & $>95$ & 20738.10 & 2421.20 & 1667.90 & 513.76 & 0.69 & 0.01 \\
\hline
\end{tabular}

Notes: $\mathrm{Fe}_{\mathrm{T}}=$ total iron content; $\mathrm{Fe}_{\mathrm{d}}=$ total iron oxides; $\mathrm{Fe}_{\mathrm{ox}}=$ amorphous iron oxides; $\mathrm{Fe}_{\mathrm{p}}=$ organically complexed iron oxides. 
Table 2. Comparison of Fe fractions $\left(\mathrm{mg} \mathrm{kg}^{-1}\right)$ over basement complex rocks.

\begin{tabular}{|c|c|c|c|c|c|}
\hline & Geology & Horizon & Mean & Std. Deviation & $p$ value \\
\hline \multirow[t]{3}{*}{$\mathrm{Fe}_{\mathrm{T}}$} & Granite gneiss & A & 13794.05 & 3553.73 & 0.45 \\
\hline & Biotite granite & & 11136.90 & 4324.93 & \\
\hline & Migmatite & & 14380.96 & 1670.22 & \\
\hline \multirow[t]{3}{*}{$\mathrm{Fe}_{\mathrm{d}}$} & Granite gneiss & & 1960.22 & 308.60 & 0.51 \\
\hline & Biotite granite & & 2536.59 & 1304.27 & \\
\hline & Migmatite & & 3820.44 & 232.12 & \\
\hline \multirow[t]{3}{*}{$\mathrm{Fe}_{\mathrm{ox}}$} & Granite gneiss & & 1411.32 & 649.61 & 0.29 \\
\hline & Biotite granite & & 1874.17 & 637.35 & \\
\hline & Migmatite & & 1167.22 & 169.09 & \\
\hline \multirow[t]{3}{*}{$\mathrm{Fe}_{\mathrm{p}}$} & Granite gneiss & & 472.48 & 60.16 & 0.02 \\
\hline & Biotite granite & & 731.65 & 307.98 & \\
\hline & Migmatite & & 177.92 & 48.43 & \\
\hline \multirow[t]{3}{*}{ Ratio $\mathrm{Fe}_{\mathrm{ox}}: \mathrm{Fe}_{\mathrm{d}}$} & Granite gneiss & & 0.70 & 0.19 & 0.01 \\
\hline & Biotite granite & & 0.80 & 0.16 & \\
\hline & Migmatite & & 0.31 & 0.06 & \\
\hline \multirow[t]{3}{*}{ Ratio $\mathrm{Fe}_{\mathrm{d}}$ :Clay } & Granite gneiss & & 0.15 & 0.04 & 0.80 \\
\hline & Biotite granite & & 0.18 & 0.08 & \\
\hline & Migmatite & & 0.17 & 0.02 & \\
\hline \multirow[t]{3}{*}{$\mathrm{Fe}_{\mathrm{T}}$} & Granite gneiss & B & 16132.66 & 2070.01 & 0.13 \\
\hline & Biotite granite & & 13666.68 & 2538.05 & \\
\hline & Migmatite & & 13964.29 & 1862.48 & \\
\hline \multirow[t]{3}{*}{$\mathrm{Fe}_{\mathrm{d}}$} & Granite gneiss & & 1725.06 & 177.28 & 0.002 \\
\hline & Biotite granite & & 2641.02 & 1077.75 & \\
\hline & Migmatite & & 3762.65 & 612.71 & \\
\hline \multirow[t]{3}{*}{$\mathrm{Fe}_{\mathrm{ox}}$} & Granite gneiss & & 1206.13 & 216.25 & 0.05 \\
\hline & Biotite granite & & 1861.44 & 876.73 & \\
\hline & Migmatite & & 916.53 & 396.41 & \\
\hline \multirow{3}{*}{$\mathrm{Fe}_{\mathrm{p}}$} & Granite gneiss & & 663.77 & 334.99 & 0.35 \\
\hline & Biotite granite & & 540.98 & 312.28 & \\
\hline & Migmatite & & 354.10 & 348.32 & \\
\hline \multirow[t]{3}{*}{ Ratio $\mathrm{Fe}_{\mathrm{ox}}: \mathrm{Fe}_{\mathrm{d}}$} & Granite gneiss & & 0.70 & 0.14 & 0.0001 \\
\hline & Biotite granite & & 0.70 & 0.16 & \\
\hline & Migmatite & & 0.25 & 0.12 & \\
\hline \multirow[t]{3}{*}{ Ratio $\mathrm{Fe}_{\mathrm{d}}$ :Clay } & Granite gneiss & & 0.08 & 0.016 & 0.002 \\
\hline & Biotite granite & & 0.11 & 0.03 & \\
\hline & Migmatite & & 0.16 & 0.04 & \\
\hline
\end{tabular}

Notes : $\mathrm{Fe}_{\mathrm{T}}=$ total iron content $\mathrm{Fe}_{\mathrm{d}}=$ total iron oxides; $\mathrm{Fe}_{\mathrm{ox}}=$ amorphous iron oxides; $\mathrm{Fe}_{\mathrm{p}}=$ organically complexed iron oxides.

$158.3-1058.7 \mathrm{mg} \mathrm{kg}^{-1}$ ) reported by Owonubi and Olowolafe (2010) for basement complex soils in the Northern guinea savanna area of Nigeria; and also higher than that reported by Bera et al. (2005) for subtropical environment (range: $840-2240 \mathrm{mg}$ $\left.\mathrm{kg}^{-1}\right)$. In contrast, there were significant differences in the distribution of organically complexed iron oxides $\left(\mathrm{Fe}_{\mathrm{p}}\right)$ estimated using sodium pyrophosphate in the A-horizons $(p<0.05)$ between soils over biotite granite and migmatite with biotite granite having the highest contents. The distribution of organically complexed iron $\left(\mathrm{Fe}_{\mathrm{p}}\right)$ in the $\mathrm{B}$ horizon was statistically similar among the geologic units $(p>0.05)$.

Soils over biotite granite and granite gneiss had similar $(p>0.05)$ active iron ratios $\left(\mathrm{Fe}_{\mathrm{ox}}: \mathrm{Fe}_{\mathrm{d}}\right)$ and both were statistically higher $(p<0.05)$ than that of migmatite. The data shows that about $70 \%$ of iron oxides in soils over biotite granite and granite gneiss are armorphous in nature although about $25 \%$ armorphous fraction was observed for migmatite. Active iron ratios in soils over biotite granite and granite gneiss were higher than that reported by Seal et al. (2006) for Alfisols in subtropical India. The 
Table 3. Descriptive statistics of Fe fractions $\left(\mathrm{mg} \mathrm{kg}^{-1}\right)$ in soils over basement complex and basaltic rocks.

\begin{tabular}{|c|c|c|c|c|c|c|c|}
\hline & & & Horizon & & $\mathrm{B} \mathrm{H}$ & izon & \\
\hline & Geology & Mean & Std. Deviation & $p$ value & Mean & $\begin{array}{c}\text { Std. } \\
\text { Deviation }\end{array}$ & $p$ value \\
\hline $\mathrm{Fe}_{\mathrm{T}}$ & $\begin{array}{l}\text { Basement } \\
\text { complex }\end{array}$ & 12987.88 & 3488.66 & 0.005 & 14752.11 & 2387.70 & 0.0001 \\
\hline & Basalt & 20188.91 & 86.53 & & 20448.40 & 395.67 & \\
\hline $\mathrm{Fe}_{\mathrm{d}}$ & $\begin{array}{l}\text { Basement } \\
\text { complex }\end{array}$ & 2677.14 & 1074.86 & 0.44 & 2527.77 & 1055.04 & 0.50 \\
\hline & Basalt & 2166.33 & 97.38 & & 2226.53 & 162.58 & \\
\hline $\mathrm{Fe}_{\mathrm{ox}}$ & $\begin{array}{l}\text { Basement } \\
\text { complex }\end{array}$ & 1513.06 & 588.53 & 0.66 & 1369.28 & 664.03 & 0.32 \\
\hline & Basalt & 1672.92 & 4.42 & & 1652.02 & 14.98 & \\
\hline $\mathrm{Fe}_{\mathrm{p}}$ & $\begin{array}{l}\text { Basement } \\
\text { complex }\end{array}$ & 486.39 & 287.57 & 0.003 & 547.57 & 332.55 & 0.98 \\
\hline & Basalt & 853.21 & 75.10 & & 550.46 & 34.82 & \\
\hline $\begin{array}{l}\text { Ratio } \\
\mathrm{Fe}_{\mathrm{ox}}: \mathrm{Fe}_{\mathrm{d}}\end{array}$ & $\begin{array}{l}\text { Basement } \\
\text { complex }\end{array}$ & 0.63 & 0.25 & 0.34 & 0.60 & 0.24 & 0.15 \\
\hline & Basalt & 0.78 & 0.04 & & 0.75 & 0.05 & \\
\hline $\begin{array}{l}\text { Ratio } \\
\mathrm{Fe}_{\mathrm{d}} \text { :Clay }\end{array}$ & $\begin{array}{l}\text { Basement } \\
\text { complex }\end{array}$ & 0.16 & 0.05 & 0.0001 & 0.11 & 0.04 & 0.0001 \\
\hline & Basalt & 0.007 & 0.006 & & 0.01 & 0.00000 & \\
\hline
\end{tabular}

ratios between total iron oxide and clay ( $\mathrm{Fe}_{\mathrm{d}}$ :clay) in the A horizons were statistically similar $(p<0.05)$ among the geologic units. These data show that total iron oxides constitute less than $20 \%$ of total clay in the soils. This result is expected due to the low weathered condition of the soils. In contrast, highly weathered soils such as Plinthosols could contain at least $80 \%$ iron oxides (FAO 1993).

\section{Comparison of Iron Fractions in Basement Complex and Basaltic Soils}

The data shows that soils derived from basement complex had significantly $(p<0.05)$ lower contents of total iron $\left(\mathrm{Fe}_{\mathrm{T}}\right)$ compared to those derived from basaltic rocks (Table 3 ). In contrast, there were similar contents of total iron oxides $\left(\mathrm{Fe}_{\mathrm{d}}\right)$, total amorphous iron oxides $\left(\mathrm{Fe}_{\mathrm{ox}}\right)$, and organically complexed iron oxides $\left(\mathrm{Fe}_{\mathrm{p}}\right)$ both in the basement complex derived soils and in soils derived from basaltic rocks $(p>0.05)$. The lower contents of total iron in the basement complex derived soils could be due to inherent lower contents of $\mathrm{Fe}$ in the basement complex rocks compared to those of basaltic rocks (Bostrom and Bach 1995; Szentes 2009; Talabi 2013). The active Fe ratios of soils over basement complex were statistically lower $(p<0.05)$ than those derived from basaltic rocks, indicating that the basaltic soils had higher proportion of amorphous iron oxides. The ratios of $\mathrm{Fe}_{\mathrm{d}}$ :clay were however higher in the basement complex derived soils than in the basaltic soils, indicating lower proportion of iron oxides relative to total clay in the basaltic soils.

\section{CONCLUSIONS}

In general, total iron fractions were statistically similar among soils of basement complex geologic units but significantly lower than those of soils derived from basaltic rocks. However, the distribution of iron oxide fractions was similar among basement and basaltic geologic units. Furthermore, there were significant differences in the distribution of iron oxides in the $\mathrm{B}$ horizons of basement complex derived soils.Consequently, the quantity of iron oxides in the $\mathrm{B}$ horizon was in the order of migmatite $>$ biotite granite $>$ granite gneiss.

Analysis of active iron ratios for basement complex derived soils showed that $70 \%$ of total iron oxides in soils over granite gneiss and biotite granite was amorphous in nature. However, for migmatite derived soils, about $25 \%$ of total iron oxides was amorphous in nature. Further analysis of active iron ratios indicated that the basaltic soils contained higher proportions of armorphous iron oxide fractions than the basement complex derived soils. 
Furthermore, $\mathrm{Fe}_{\mathrm{d}}$ :clay ratios indicated that the total iron oxides constitute less than $20 \%$ of total clay both in basement complex and basaltic soils. However, $\mathrm{Fe}_{\mathrm{d}}$ :clay ratios in the basaltic soils were much lower than in the basement complex derived soils, indicating that the basaltic soils have lower proportion of iron oxides relative to total clay.

\section{ACKNOWLEDGEMENTS}

My heartfelt gratitude goes to Professor E. A. Olowolafe at the Department of Geography and Planning, University of Jos; Nigeria for supervising this research and for the mentoring me.

\section{REFERENCES}

Bera R, A Seal, M Banerjee and AK Dolui. 2005. Nature and profile distribution of iron and aluminum in relation to pedogenic processes in some soils developed under tropical environment in India. $J$ Environ Geol 47: 241-245.

Bostrom K and W Bach. 1995. Data report: chemical analyses of basaltic rocks: an interlaboratory comparison. In: R Batiza, MA Storms and JF Allan (eds). Proceedings of the ocean drilling program, scientific results, $142 \mathrm{p}$.

Fagbami A and FO Ajayi. 1990. Valley bottom soils of the sub-humid tropical southwestern Nigeria on basement complex: characteristics and classification. JPN Soc Soil Sci Plant Nutr 36: 179-194.

FAO. 1993. World soil resources: An explanatory note on the FAO world soil resources map at 1:25, 000, 000 scale. World Soil Resources Report No. 66 Rev. 1. Food and Agriculture Organization (FAO), Rome.

Ko T. 2014. Nature and Properties of Lateritic Soils Derived from Different Parent Materials in Taiwan. The Scientific World J4 p. doi: 10.1155/2014/247194.

Macleod WN, DC Turner and EP Wright. 1971. The geology of the Jos Plateau. Geol Surv Nig Bull 32: $1-2$.
Mehra OP and ML Jackson. 1960. Iron oxide removal from soils and clays by dithionite citrate system buffered with sodium bicarbonate. Clays and clay miner 7:317-327.

McKeague JA. 1967. An evaluation of $0.1 \mathrm{M}$ pyrophosphate and pyrophosphate-dithionite in comparison with oxalate as extractants of the accumulation products in Podzols and some other soils. Can J Soil Sci 47: 95 -99.

Olatunji OO, Y Oyeyiola and GO Oyediran. 2015 Assessment of Dithionite and Oxalate Extractable Iron and Aluminium Oxides on a Landscape on Basement Complex Soil in South-Western Nigeria. J Soil Sci 5: 266-275. doi: 10.4236/ojss.2015.511025.

Olowolafe EA. 2002. Soil parent materials and soil properties in two separate catchment areas on the Jos Plateau, Nigeria. Geo Journal 56: 201-212.

Owonubi A and EA Olowolafe. 2010. Pedogenic forms of iron and manganese in soils of a landscape in Samaru, Nigeria. Niger J Sci Tech 6: 176-187.

Porras RC, CEH Pries, KJ McFarlane, PJ Hanson and MS Torn. 2016. Association with Pedogenic Iron and Aluminum: Effects on Soil Organic Carbon Storage and Stability in Four Temperate Forest Soils. Biogeochemistry, LLNL-JRNL-708394.

Seal A, R Bera, P Bhattacharyya, K Mukhopadhyay and R Giri. 2006. Degree of Soil Development in Some Alfisols of Subtropical India with Special Reference to the Nature and Distribution of Fe and Al. Int $J$ Agric Res 1: 305-311.

Szentes G. 2009. Granite formations and granite cavities in northern Nigeria. Cad Lab Xeol Laxe 34: 13-26.

Talabi AO. 2013. Mineralogical and chemical characterization of major basement rocks in Ekiti state, SW - Nigeria. RMZ - M\&G 60: 73-86.

Vance DB. 1994. 2 The 4 Technology: Iron - The environmental impact of a universal element. Nat Environ J 4: 24-25.

Wagai R and LM Mayer. 2007. Sorptive stabilization of organic matter in soils by hydrous iron oxides. Geochim Cosmochimica Acta 71: 25-35.

Yaro DT. 2005. The position of plinthite in a landscape and its effect on soil properties. Unpublished $\mathrm{PhD}$ dissertation, Ahmadu Bello University, Zaria, Nigeria. 